\title{
Protection of Computer Programs in Industrial Revolution 4.0 Era: From Indonesian Legislation Perspective
}

\author{
Satya Arinanto \\ University of Indonesia, Jakarta, Indonesia \\ Ike Farida \\ Hitotsubashi University, Tokyo, Japan
}

\begin{abstract}
The Industrial Revolution Era 4.0 encouraged the development of innovative computing systems that bring forth to innovations in information technology that were diverse and beneficial to the wider community. Computer programs developed as part of the software which one of the factors that influence the diversity of information technology. Today, computer programs have been recognized as valuable assets for companies and individuals who created or discovered them. Legal protection for inventions in all fields of technology including computer programs in several countries is carried out through patent registration as regulated in Article 27(1) of the Trade-Related Aspects of Intellectual Property Rights (TRIPs). Protection of inventions in the field of information technology by the Patent Law in Indonesia is currently limited only in the scope of hardware, while the protection of computer programs is regulated by Law No. 28 of 2014 concerning copyright. The regulation through copyright law is considered insufficient to protect inventions in the field of information technology. Some developed countries in the world, such as Japan and the United States regulate the protection of computer programs through patents. This research will use the normative juridical method using secondary data. Furthermore, this research will examine the protection of computer programs based on the laws in force in Indonesia. The results of the study are expected to be able to provide input and thought contributions in order to build a computer system protection system in Indonesia.
\end{abstract}

Keywords: protection, information technology, computer programs

\section{Background}

Technology is an inseparable part of the increasingly advanced developments in the industry. This is seen through the development of computing systems in the Industrial Revolution Era 4.0, which one of the aims is to increase productivity in the industrial field. The Preamble to the 1945 Constitution of the 4th paragraph as staat fundamental norms or basic norms, provides the mandate for the government to be directly involved in this digital era. The involvement, if elaborated, is to protect the entire Indonesian nation, advances public welfare, and enlightens the life of the nation. One of the forms of the embodiment is legal protection in the field of information, communication and technology (ICT) both to hardware and software.

Satya Arinanto, S.H., M.H., Dr., professor, Faculty of Law, University of Indonesia, Jakarta, Indonesia.

Ike Farida, S.H., LL.M, Dr., Faculty of Law, Hitotsubashi University, Tokyo, Japan. 
The protection of ICT as a form of respect for ideas, works, and inventions for inventors in technology is also regulated internationally through Article 27 Paragraph 2 of the Law on the Declaration of Human Rights whereby "Everyone has the right to be protected both morally or material obtained from scientific, literary and artistic creation in a case that they are the creator” (United Nation, 1948, §27[2]). The concept of protection becomes embodiment of the spirit protection of copyrighted works including computing, technology, and information into various regulations known as intellectual property. In Indonesia, computer programs in the form of languages, codes, schemes, or in other forms are classified as software that is part of copyright. Whereas ideas or creative works that are specific in the field of technology and products that are in the process of experiencing improvements or referred to as hardware, are protected through patents.

Both copyright and patent rights are two instruments that have differences in regulation. Besides that, both of them also have sliced equations that cannot be separated from one another. Indonesian Law 28 of 2014 concerning copyright provides definitive that protected objects are limited to tools or forms that can process and relate to technology, whereas in Indonesian Law No. 13 of 2016 concerning patents emphasizes the protection of works which are literary, art, language, poetry, and computer programs. Apart from these differences, both the copyright law and patent rights actually intend to provide protection for ICT.

Legal protection and exclusive recognition of ICT by the government is an effort to encourage the community to be more innovative and creative. In return, the community is expected to have awareness in order to register patents and copyrights in Indonesia. While actually, the concept of copyright places more emphasis on the concept of economic and industrialist exclusivity that is sustainable for the owner of the creation.

In some countries, the classification of computer programming protection into patents or copyrights is still an open legal policy. Common law countries, such as Japan and the United States include computer programs in patents, while in Indonesia, programming protection is done through copyrights. However, these arrangements are not limited due to certain conditions, computer programming can be completed through patents but must meet several conditions inside.

Violation of an invention caused by the inventor in the field of information, communication and technology (ICT) is something that must be considered by the government. The loss from this violation is not only detrimental to the owner of exclusive rights or inventors, but also a potential harm to the country. This is because, the lack of protection towards programming will reduce the power of innovation in society. However, before carrying out the settlement, the government must consider very well to provide regulations for technology, information, and communication including computer programs.

Referring to the background above, the problem of the research can be formulated as follows:

How does the protection of computer programs work through copyright?

How is the protection of computer programs based on the rights of patents?

\section{Discussion}

\section{Protection of Computer Programs Through Copyright}

Provision of copyright protection for computer programs in the world began to be implemented in the late 1980s. Before that, legal experts and courts in the world assumed that computer programs did not belong to the category of works that could be protected by copyright, because computer programs did not have the 
characteristics of a literary or artistic work and the shape was intangible. In fact, to obtain copyright protection, a work must be a written work or in the form of art and must be displayed in tangible form.

A computer program is a type of software, which is one of the inventions in the field of information and communication technology (ICT). Protection of computer programs in Indonesia is regulated in Law No. 28 of 2014 concerning copyright which adopts the provisions of TRIPs.

The TRIPs Agreement is an agreement which is part of the WTO Agreement signed by member of countries that require all members to make rules regarding intellectual property rights in their respective countries. TRIPs itself does not protect intellectual property rights internationally. In the international sphere, each field of intellectual property has its own international conventions as they develop over time. For the application of general rules that have been agreed upon, it is up to the enactment and full regulation for the state to apply the rules in its national law.

The intellectual property rights (IPR) protection standards set out in the TRIPs Agreement are very laden with the interests of developed countries. Countries deemed to have violated IPR may be subject to retaliation and cross retaliation in the form of trade sanctions. Of course, developed countries are better equipped than developing countries or underdeveloped countries, because so far they have mastered the latest science and technology. In relation to the regulation of copyright in Indonesia, the harmonization of IPR laws and regulations should not only be based on pressure from developed countries but also because of the reasons for the discovery, inventions, and intellectual works of Indonesian citizens, which in the future can create nation independence in the field of science, technology to support national development (Irawan, 2011).

\section{Protection of Computer Programs in Indonesia}

In Article 1 Paragraph 9, it defines a computer program as a set of instructions that are expressed in the form of language, code, scheme, or in any form intended for the computer to perform certain functions or to achieve certain results (Copyright Law of Indonesia, 2014, UU No. 28 Tahun). From this definition, it can be seen that computer programs have a high value, not only for individuals but also companies. In addition, regarding computer programs in the Copyright Act, it is very clear that the realization of ideas from program creators (software developers) by compiling a formulation of instructions and codes requires a high intellectual ability. The works mentioned in the Copyright Law also include works that are not or have not yet been announced but have already taken shape as a tangible form of unity.

The protection provided by the Copyright Act is optimistic because it adheres to a declarative system where legal protection is given to computer programs automatically when the creation is born in a concrete form. This can be interpreted that the protection of computer programs is provided without having to be registered first. Even so, it is highly recommended for creators or owners of computer programs to include copyright notices on their computer programs specifically to obtain worldwide copyright protection and to prevent defenses based on innocent infringers (inadvertent piracy)

On the other hand, Article 40 Paragraph 1 states that protected works is including works in the fields of science, art, and literature, consisting of:

a. Books, pamphlet, published typographical papers, and all other written words;

b. Discourse, lectures, speeches, and other similar creations; 
c. Teaching aids made for educational interest and science;

d. Song and/or music with or without text;

e. Drama, musical drama, dance, choreography, puppet show and pantomime;

f. Works of art in any forms such as paintings, drawings, engravings, calligraphy, sculpture, or collage;

g. Applied art;

h. Architectural words;

i. Map;

j. Batik artwork or other pattern art;

k. Photography works;

l. Portrait;

m. Cinematographic works;

n. Translations, interpretations, adaptations, anthologies, databases, arrangements, modifications and works other from the results of transformation;

o. Translation, adaptation, arrangement transformations, or modification of traditional cultural expressions;

p. Compilation of creation or data, both in a format that can be read by a computer program as well as other media;

q. Compilation of traditional cultural expressions as long as they are original works;

r. Video game;

s. Computer program.

This indicates that the technology sector is not called a creation that can be protected by copyright. In Article 40 Paragraph 1, one of the creations that can be protected is a computer program, while a computer program is a type of technology in the field of information and communication technology (ICT).

A quality computer program copyrighted work will cause many people trying to use it and benefiting from the computer program. Thus, a computer program is useful and has a significant influence on the progress of a nation, because it is only natural that a computer program for its creator receives an award. Armed with copyright owned by the creator, legal protection is needed. Such protection is in the form of efforts to avoid or prevent acts of copyright infringement on a work.

All computer programs are given copyright protection, computer programs themselves are generally divided into two groups:

1. The system program, which is the program that controls the entire process of a computer system even though at this time the computer program is to be made the same or almost the same.

2. Applied programs or application programs, namely computer programs created to solve a particular problem.

Both computer programs are given copyright protection. In addition, based on the nature of a computer program, actually in general, the computer program based on its form is divided into two forms, namely (Marlyna \& Sherliana, 2008):

(1) Source code. Source code is a program file that contains programming statements, instruction codes, commands, functions, and objects created by a programmer. Source code is an expression of the creator, where the creator writes the codes (codes) or design the code so that it allows a computer program to do a certain command. 
(2) Object code. Object code comes from the word object which means object or destination and code which means password, code, typed commands, and symbols that have meaning. So, object code means it is considered to be related to machine language that is obtained after the program code has been compiled. Source code that is entered into the computer in the software that generally exists in the terminal then this source code will be changed into machine language by the compiler or interpreter called the object code. The source code that has been compiled or interpet is called an object code. This object code is referred to by the Copyright Act as a literary work.

Programs written in this special language are called source code and the results translated into machine language are called object codes. This source code and object code are protected in the copyright law in Indonesia.

In the Era of the Industrial Revolution 4.0, various things can be accessed digitally which supports the improvement of computer program inventions. Along with the development, there were also many violations. Copyright infringement in the field of computer programs other than due to the practice of reproduction and distribution without permission from the copyright holder there are also other factors, namely if between two computer programs have the same source code, then it is possible to have an impersonation of one computer program. The concept of the Copyright Act does not provide quantitative protection, which governs how much the similarity is between the two computer programs. In the Indonesia copyright law, the license usually includes the provisions as follow:

1. The software may be installed only on one machine;

2. It is prohibited to reproduce the software for any purpose (usually the user is given the opportunity to make one backup copy);

3. It is forbidden to lend the software to others for any purpose.

Based on the above restrictions, the act of installing computer programs into more than one machine or outside the provisions issued by one license, borrowing and borrowing computer programs and installing them or reproducing those computer programs, can be categorized as piracy.

Legal protection provided by the copyright system is often considered unable to provide adequate legal protection. This is because copyright law cannot reach independent creations which similar with the ideas contained in a computer software.

\section{Reasons Computer Programs Are Subject to Copyright Protection}

Copyright is the exclusive right of the creator that arises automatically based on the declarative principle after a work is realized in tangible form without reducing restrictions in accordance with statutory provisions (Copyright Law of Indonesia, 2014, Art. 1, Number 1). In addition, copyright includes two other rights, namely, moral rights and economic rights. Both of these rights are regulated in Articles 5 to 19 Indonesia Law No. 28 of 2014 concerning copyrights.

Protection of computer programs is regulated in copyright with considerations, such as:

1. The period of copyright protection is much longer, namely 50 years since it was first announced (Copyright Law of Indonesia, 2014, Art. 59, Number 1). The length of the protection of computer programs provided by copyright is more beneficial for programmers/creators and companies who create the computer 
programs, because along with the long period of copyright protection, the creator and company get a longer economic value from the computer program. The same is true of protection against infringement concerning copyright.

2. When compared with patent protection, programmers will be more flexible in modifying programming algorithms without fear of violating patents, because this programming algorithm is not protected in the domain of copyright in Indonesia, so this will increase creativity and encourage programmers to create more innovative computer programs.

3. Protection of computer programs with a copyright mechanism is easier when compared to patents because the protection of computer programs patents requires that a computer program must be new, contained with the inventive steps and can be applied in industry.

The weakness of the protection of computer programs with a copyright mechanism is only in the presence of fair use where the user of a computer program is permitted to duplicate a computer program that he bought for personal gain without the need of permission from the copyright holder of the computer program. This mechanism makes a lot of abuse to duplicate the computer program to be spreaded to other parties and get economic benefits from it.

Regulations regarding computer programs as one of the works of copyright in the field of science generally follow the results of other copyrighted works. In the case of the creation of a computer program that is identical to a computer program that has existed before then the new computer program is considered not to violate copyrights as long as the newly created computer program is not plagiarized by an existing computer program. Copyright protection of computer programs is a literal expression. However, judging from the current situation, there are a number of computer programs whose literal expressions are closed so that they cannot be protected by copyright. So, protection is needed more flexibly, but able to accommodate the interests and minimize violations that harm both the creator, the company, and users.

\section{Protection of Computer Programs Through Patents}

Protection of computer programs through patents in other countries and in Indonesia. Historically, computer protection through patents is unknown and unrecognized. Patent offices in several countries in Europe and the United States are not willing to qualify a computer program as an invention that can be granted a patent (Japan Patent Office and Asia Pacific Industrial Property Center, n.d.). The refusal to qualify for a computer program was followed by a rejection of the software industry which resulted in the European Patent Office (EPO) changing the EPO Guidelines to:

Although a computer program is not a patent subject, and it will not be a patent subject even though the computer program has been downloaded on a computer, but if it is on a device, the granting of a patent on that subject may not be impeded on the grounds that to run the subject the computer program is used

The debate over whether computer programs could be legally protected through the patent system had begun since 1966. At that time, the patent system commission formed by President Johnson who filed a report opposing the granting of patents for computer programs on the grounds that computer programs were not included as a process as regulated in the United States Patent Law (Sinaga, 2010). Legal protection through a patent system for computer programs related to the invention in the United States began in 1981. Legal protection through the patent system was initiated by the Diamond and Diehr (1981). In the Diamoizd 11. Diehr case, the US Supreme 
Court ordered the United States Patent and Trademark Office to provide patents for inventions using computer programs. Related inventions in Diamond and Diehr is an invention related to a method for curing rubber.

With regard to the case, the United States Supreme Court issued a rule requiring the United States Patent and Trademark Office (USPTO) to grant a patent on an invention filed by Diehr (Diamond \& Diehr, 1981).

To accommodate the rapid developments related to inventions related to computer programs, USPTO issued the Examination Guidelines for Computer-Related Inventions in 1996, there are three important things regulated in the guideline, namely:

1. The type of invention that can be patented must have practical applications and be included in the field of technology

2. Ideas that are merely abstract or processes that manipulate mathematical algorithms are not included in the invention. However, if the idea or algorithm can be applied practically, the idea or algorithm can be considered a process claim.

3. Although data structures are not considered subject matter that can be patented, such data structures can still be considered as inventions if the data structures are stored in a computer-readable media.

The guidelines also regulate the specifications of patent applications containing related computer programs as follows (Sinaga, 2010, p. 5):

For a Computer-related invention, the disclosure must enable a skilled artisan to configure the computer to possess the requisite functionality, and where applicable, interrelate the computer with other elements to yield the claimed invention, without the exercise of undue experimentation. The specification should disclose how to configure a computer to possess the requisite functionality or how to integrate the programmed computer with other elements of the invention, unless a skilled artisan would know how to do so without such disclosure.

In some other countries in Europe, mathematical algorithms which are the basis for improving the functioning of computer software, can be protected by patents, while in other countries, computer software is explicitly excluded as things that cannot be patented. In these countries, inventions related to software can still be patented, if the software is considered to have made a technical contribution to the previous invention.

Article 52 of the European Patent Convention provides software exemptions from patent capabilities insofar as patent applications are related to computer programs. However, a distinction must be made between "software patents" that are excluded according to Article 52 of the European Patent Convention (EPC) and the so-called computer-implemented inventions received at the European Patent Office. In this case, "inventions implemented by computers" can be defined as discoveries whose implementation involves the use of computers, computer networks, or other programmable equipment, which has one or more features realized through a computer program. Therefore, it seems that patents should not be denied just because there is a computer program.

Although among European countries that have signed the European Patent Convention and already adjusted their national legislation, there are still different interpretations of the concept of the patent protection scope. As stipulated in Article 69 Paragraph 1 of the European Patent Convention, it states: The extent of the protection conferred a large European or European patent application shall be determined by the large terms of claims. Nevertheless, the description and drawings shall be used right interpret the claims. For the Netherlands, this is stated in Article 30 Paragraph 2 of the 1986 Dutch Law, which essentially determines that the protected is the content of the claim, not the literal formulation of the claim included in the patent application for an invention. 
Meanwhile, Patent Cooperation Treaty (PTC) divides patent protection as follows:

1. "National patent" is a patent granted by a national agency;

2. "Regional patent" is a patent granted by a national agency or intergovernmental agency that has the authority.

3. To grant patents that apply to more than one country, "regional patents" are new and different from the national patent protection at first. So, it is possible for an innovation to be protected not limited to one country but several countries.

Referring to the provision in Article 27 Number 1, TRIPs has explained that the subject of patents can be applied to any invention, both products and manufacturing processes in the field of technology, meets new elements, and there are steps that can be applied to industrial activities. This includes the computer program.

In Indonesia, Law No. 13 of 2016 concerning patents (Patent Law) provides legal protection for inventions in the field of technology both in the form of processes and products. Patents are granted for works or ideas of invention in the field of technology, which after being processed can produce a product or a process only (Usman, 2003). Then, when its utilized, it will bring economic benefits as well. This is what gets legal protection. Naturally the legal protection provided is not automatic, there must be prior application.

Information and communication technology (ICT) as part of science and technology (Ilmu Pengetahuan dan Teknologi, IPTEK) in general are all technologies related to the collection, acquisition, processing, storage, dissemination, and presentation of information through computer programs (Indonesia Ministry of Research and Technology, 2005). In the explanation of Article 4 Letter D, what is meant by "rules and methods that only contain computer programs" are computer programs that only contain programs without character, technical effects, and problem solving, but if the computer program has characters (instructions) that have technical effects and functions to produce problem solving both tangible and intangible are inventions that can be patented.

Examples of inventions that can be patented include: (1) Algorithms, which are effective methods expressed as a limited set of well-defined instructions for calculating a function. Starting with an initial condition and initial input (possibly empty), the instructions describe a computation which, when executed, is processed through a finite number of well-defined sequence conditions, which ultimately results in "output" and stops in the final condition. The transition from one condition to the next does not have to be deterministic; some algorithms, known as randomization algorithms using random input; and (2) encrypting information by encoding and decoding to randomize so that the information cannot be read by other parties (Atsar, 2017).

If a contrario is interpreted (according to denial), this means that based on Article 4 of Law No. 13 of 2016 concerning patents, means "rules and methods which not only contain computer programs" can be used as patent objects. If the computer program has characters (instructions) that have technical effects and functions to produce problem-solving, both tangible and intangible, it is an invention that can be patented (Atsar, 2017).

The urgency of the protection of computer programs through patents. The case of Stac Electronics' vs. Microsoft Inc. Stac provides a clear example that the ideas and principles which underlies computer programs cannot be protected by copyright as literary works and must be protected by patents, which is consider a much broader spectrum of protection. Because patent protection prevents someone from getting the same results in certain fields of art, from the subject of patents. As patent protection for computer programs will allow patent holders to limit all from using the technical ideas as core in their inventions. 
In addition, an understanding of computer programs that do not always involve non-technical issues is not good in practice. And finally the point raised in supporting patent protection from computer programs is that developing computer programs requires a lot of investment in skilled human resources and costing time and money on expensive equipment, besides spending on the infrastructure needed to set up a software development unit.

Moreover, if the developer or investor does not get adequate protection for his invention, this might hamper the growth of the computer industry and this might become an obstacle in the use of computers in other fields of industrial and social use. Because computer usage is proven in all areas of life, it makes things a lot easier. The overall efficiency and cost effectiveness of a process multiplies. Another factor is the rate at which technology in the computer field is considered obsolete in a short span of time.

The strength and breadth of protection afforded by patent law are the main reasons for protecting computer programs through the patent system. Specifically regulated through patent law, patent owners can prevent all others from making, using, or selling patented inventions. Patent protection protects the ideas or technical principles that underlie the basis behind the invention.

That is inversely proportional to the protection of computer programs that can be given by copyright in practice is very limited. Limited copyright protection cannot reach if there is a reversed engineering of a computer program. As it is known, copyright does not provide protection for basic ideas, but only provides protection for works that have been realized in material form. Infringement of Intellectual Property Rights by taking the basic code of a computer program and studying the flowchart and function of the codes and then creating new codes based on what has been learned is not regulated and is not specifically protected. Another problem is that in the case of the creation of an identical computer program with other pre-existing computer programs, the new computer program will not violate the copyright of existing computer programs.

The biggest advantage given to patent protection for copyright is the fact that it protects the ideas or concepts that underlie this invention. Patents can protect some of the features contained in the program and the processes carried out by the program. Indeed, such protection is necessary because of the rise of business on the Internet, which greatly facilitates the copying and transmission of computer programs in the four corners of the world. Another advantage is the fact that patent protection not only applies to copiers, but also to independent inventors. Indeed, patents protect against competitors who create the same results without copying.

The advantages mentioned above are in line with Daerwan Koo's opinion regarding various advantages of patent protection for computer programs (software patents), including (Barbosa, 1985):

1. Patents can protect the idea of the concepts underlying the invention, where the concept is likely to have enormous value.

2. Patents provide protection not only against software piracy but also against other inventors. Here we see an aspect of the economic benefits of patents, where patent licensing can be a potential source of income

3. The existence of a large incentive for the bearer and disseminator of new technology through software patents can increase the sale value of certain companies above their competitors.

Another advantage of protecting computer programs through a patent mechanism is that the owner of a software or computer program can take action against anyone who creates a program that has similarities 
the patented computer program. Although the process of making the software is made independently and does not plagiarize. In addition, patent protection will provide computer program protection against reverse engineering. $^{1}$

In general, there are at least four main rights that will arise if the protection of computer programs is regulated in the law on patents that is closely related to technological interests and economic interests. First, the patent holder has an exclusive right to exercise his patent, and prohibits others, without his consent, to use and/or develop the patent. Second, the patent holder has the right to grant licenses to others based on a license agreement. Third, the patent holder has right to sue for compensation through the court to whom intentionally and without the right to perform prohibited acts as determined. Fourth, the patent holder has the right to sue anyone who intentionally and without the right to perform prohibited acts as determined.

As a comparison, the patentability requirements for computer program inventions in Japan have the "statutory invention" requirement. The concept of "statutory invention" is based on the following scopes:

Where information processing by software is concretely realized by using hardware resources, said software is deemed to be "a creation of technical ideas utilizing the laws of nature".

Where point (1) satisfied, the information-processing device (machine) and operational methods thereof, which work in concert with said software, and the computer-readable storage medium on which said software is recorded are also deemed to be "creations of technical ideas utilizing the laws of nature” (Japan Patent Office and Asia Pacific Industrial Property Center, n.d.)

Nevertheless, there is an absolute necessity for a specification or qualification for a patent application with an invention related to a computer program in detail and clearly, so there is no overlapping between the protection done through copyright and patents.

\section{Conclusion and Recommendation}

\section{Conclusion}

Protection of computer programs in Indonesia is regulated in Law No. 28 of 2014 concerning copyright. However, this law is not yet able to provide protection for computer programs. This is proved by the remaining cases of copyright infringement in Indonesia.

Patent computer program protection in Indonesia is currently limited to hardware protection only, but in the provision of Article 40 Paragraph 1, the Patent Law provides space implicitly regulating technical computer programs. This has intensified the impartiality of computer program settings in Indonesia, meaning that computer program inventions have not been protected as a whole.

\section{Recommendation}

To reduce copyright cases especially related on computer programs, Indonesia should be regulated protection of computer programs on patent regulation

There should be a specification/qualification of a patent application with an invention related to a computer program in detail and clearly in order to avoid the overlapping between the intellectual property protection done through copyright and patent.

\footnotetext{
${ }^{1}$ Reverse Engineering, http://www.weha.web.id accessed on 31 January 2020.
} 


\section{References}

Atsar, A. (2017). Comparison on regulation of protection against invention in technology and communication between Indonesia and Japan. Jurnal Hukum dan Pembangunan, 47(3), 316. (in Indonesian)

Barbosa, D. B. (1985). Software and copyright: A marriage of inconvenience. In A. Lucas (Ed.), La Protection des creations industrielles abstraites. Lib: Tenchiquest.

Copyright Law of Indonesia. (2014). Retrieved from https://en.wikipedia.org/wiki/Copyright_law_of_Indonesia

Diamond \& Diehr (1981). Retrieved February 20, 2020, from http://supreme.justicia.com/us/450/175/case.html

Indonesia Ministry of Research and Technology. (2005). White book: Development research and application of information and technology year 2005-2025. Jakarta: Kementrian Riset dan Teknologi. (in Indonesian)

Irawan, C. (2011). Politics of Indonesian intellectual property law: Critic towards WTO/TRIPs Agreement and effort to established intellectual property law for national interest. Bandung: Mandar Maju. (in Indonesian)

Japan Patent Office and Asia Pacific Industrial Property Center. (n.d.). Guidelines for examination in the EPO protection of software related invention in Europe and Japan, Part C, Chapter IV, Article 52(3), p. 3.

Marlyna, H., \& Sherliana, P. (2008). Copyrights protection of computer software based on law Number 19 Year 2002 concerning copyrights. Lex Jurnalica, 5(2), 199-120. (in Indonesian)

Sinaga, R. (2010). Patent for invention related to software computer. Media Buletin Informasi dan Keragaman HKI, 6(VII), 5.

United Nation. (1948). Universal declaration of human rights. Retrieved from https://en.wikipedia.org/wiki/Universal_Declaration_of_Human_Rights

Usman, R. (2003). Legal rights in protection of intellectual property and its legal dimension in Indonesia. Bandung: Alumni. (in Indonesian) 